\title{
Hill Reaction Inhibitors Formed on Oxidative Metabolism of Phenylurea Herbicides
}

\author{
Takashi Suzuki and John E. CASIDA \\ Pesticide Chemistry and Toxicology Laboratory, Department of Entomological Sciences, \\ University of California, Berkeley, California 94720 USA
}

(Received November 15, 1979)

\begin{abstract}
Metabolites of diuron, methazole and linuron formed by mouse microsomal oxidases were analyzed with a chloroplast/2,6-dichlorophenolindophenol system for visualizing Hill reaction inhibitors on $t l c$ plates and in the first two cases with ${ }^{14} C$-labeled substrates. Each compound yields $3,4-\mathrm{Cl}_{2}-\phi-\mathrm{NHC}(\mathrm{O}) \mathrm{NHCH}_{3}$ and other metabolites potent as Hill reaction inhibitors. $\mathrm{N}$-Methyl hydroxylation and subsequent oxidation or dealkylation yield 3,4-- $\mathrm{Cl}_{2}-$ $\phi-\mathrm{NHC}(\mathrm{O}) \mathrm{R}$ metabolites where $\mathrm{R}$ is: $-\mathrm{N}\left(\mathrm{CH}_{3}\right) \mathrm{CH}_{2} \mathrm{OH},-\mathrm{N}\left(\mathrm{CH}_{3}\right) \mathrm{CHO},-\mathrm{N}\left(\mathrm{CH}_{2} \mathrm{OH}\right)_{2},-\mathrm{NHCH}_{3}$, $-\mathrm{NHCH}_{2} \mathrm{OH},-\mathrm{NHCHO}$ and $-\mathrm{NH}_{2}$ from diuron; $-\mathrm{N}\left(\mathrm{CH}_{2} \mathrm{OH}\right) \mathrm{OCH}_{3}$ and $-\mathrm{NHOCH}_{3}$ from linuron. Other reactions involve oxidative $\mathrm{N}$-demethylation of methazole, oxidative $\mathrm{O}_{-}$ demethoxylation of linuron, and reductive cleavage of methazole, the latter two reactions yielding 3,4- $\mathrm{Cl}_{2}-\boldsymbol{\phi}-\mathrm{NHC}(\mathrm{O}) \mathrm{NHCH}_{3}$. Another oxidative metabolite of diuron and cleavage product of methazole is the isourea-N-oxide, $3,4-\mathrm{Cl}_{2}-\phi-\mathrm{N}(\mathrm{O})=\mathrm{C}(\mathrm{OH}) \mathrm{NHCH}_{3}$.
\end{abstract}

\section{INTRODUCTION}

An understanding of pesticide mode of action requires definition of the metabolic pathways and determination of the biological activities of the metabolites. Most herbicides block photosynthesis at sites detectable as inhibition of the Hill reaction. ${ }^{1)}$ When active metabolites are formed, they usually arise from oxidative mechanisms. ${ }^{1,2)}$ We therefore developed procedures to examine oxidative metabolites of herbicides active as photosynthetic inhibitors.

Diuron and linuron were examined because of their potency as photosynthesis inhibitors ${ }^{1)}$ and ease of oxidative metabolism. ${ }^{2)}$ Methazole was also considered because it serves as a metabolic precursor for some of the same metabolites formed from diuron and linuron. ${ }^{2,3}$ Enzymatic systems were used in preference to organismal systems for ease of manipulation, quantitation and metabolite accountability. Mammalian microsomal oxidases were employed since they oxidize urea herbicides at a variety of sites and are easier for routine use than plant oxidases which generally yield the same metabolites. ${ }^{2,4)}$ Metabolites were detected by using radiolabeled substrates and a chloroplast/dye system for direct visualization of Hill reaction inhibitors on $t l c$ plates.

\section{MATERIALS AND METHODS}

The abbreviation Ar is used to designate a 3,4-dichlorophenyl substituent. Ureas and their $N$-methyl and $N$-methoxy derivatives were synthesized from ArNCO and the appropriate amines. $N$-Hydroxymethyl and $N-$ formyl analogs were prepared by reacting the corresponding ureas with formaldehyde and formic acid, respectively. Unstable $N$-hydroxymethyl compounds were converted to their alkoxymethyl derivatives by treatment with methanol or ethanol in the presence of conc. $\mathrm{H}_{2} \mathrm{SO}_{4}$. The required isourea- $N$-oxide $\left[\mathrm{ArN}(\mathrm{O})=\mathrm{C}(\mathrm{OH}) \mathrm{NHCH}_{3}\right]$ was obtained by alkaline treatment of $\operatorname{ArN}(\mathrm{OH}) \mathrm{C}(\mathrm{O}) \mathrm{NHCH}_{3}$, which was synthesized from $\mathrm{ArNHOH}$ and $\mathrm{CH}_{3} \mathrm{NCO}$. $\left[{ }^{14} \mathrm{C}\right.$-carbonyl $]$ diuron was provided by $\mathrm{F}$. S. Tanaka (Metabolism and Radiation Research Laboratory, United States Department of 
Agriculture, Fargo, North Dakota, USA) and $\left[{ }^{14} \mathrm{C}\right.$-phenyl]methazole by $\mathrm{H}$. W. Dorough (University of Kentucky, Lexington, Kentucky, USA).

Microsomal oxidase reactions in $2.5 \mathrm{ml}$ of $0.1 \mathrm{M}$ phosphate buffer ( $\mathrm{pH} 7.4$ ) contained mouse microsomes equivalent to $100 \mathrm{mg}$ (for diuron and linuron) or $200 \mathrm{mg}$ (for methazole) fresh liver weight, NADPH $(2.2 \mu$ moles $)$ and unlabeled or ${ }^{14} \mathrm{C}$-labeled substrate $(5 \mu \mathrm{g})$ added last in acetone $(5 \mu \mathrm{l})$ with immediate mixing. Incubations were carried out at $37^{\circ} \mathrm{C}$ with shaking in air for $20 \mathrm{~min}$. The ether-soluble metabolites of $\left[{ }^{14} \mathrm{C}\right]$ diuron and $\left[{ }^{14} \mathrm{C}\right]$ methazole were identified by two-dimensional $t l c$ chromatography with authentic standards from synthesis using derivatization by methylation or ethylation when appropriate. Tlc was also used to compare the ether-soluble metabolites of linuron with authentic standards. Hill reaction inhibitory compounds were visualized by a spinach chloroplast/2,6-dichlorophenolindophenol (DCPIP) technique similar to a described system. ${ }^{5}$

\section{RESULTS}

$\left[{ }^{14} \mathrm{C}\right]$ Diuron and $\left[{ }^{14} \mathrm{C}\right]$ methazole give four to eight ${ }^{14} \mathrm{C}$ metabolites, most of which are also detected as photosynthesis inhibitors, and linuron gives three Hill reaction inhibitors (Fig. 1). Diuron and linuron are very potent inhibitors whereas methazole is not detected with the chloroplast/DCPIP system. Each of these herbicides yields $\operatorname{ArNHC}(\mathrm{O}) \mathrm{NHCH}_{3}$, a highly potent Hill reaction inhibitor. Formation of this metabolite is optimal under oxidative conditions for diuron and linuron and reductive conditions for methazole. Other highly potent metabolites include $\operatorname{ArNHC}(\mathrm{O})$ $\mathrm{N}\left(\mathrm{CH}_{2} \mathrm{OH}\right) \mathrm{CH}_{3}$ from diuron and $\operatorname{ArNHC}(\mathrm{O})$ $\mathrm{N}\left(\mathrm{CH}_{2} \mathrm{OH}\right) \mathrm{OCH}_{3}$ and $\mathrm{ArNHC}(\mathrm{O}) \mathrm{NHOCH}_{3}$ from linuron.

The inhibitory activity of the $-\mathrm{N}\left(\mathrm{CH}_{2} \mathrm{OH}\right)$ $\mathrm{CH}_{3}$ and $-\mathrm{N}\left(\mathrm{CH}_{2} \mathrm{OH}\right)_{2}$ compounds may be due to their degradation to the $-\mathrm{NHCH}_{3}$ and $-\mathrm{NHCH}_{2} \mathrm{OH}$ derivatives, respectively, by formaldehyde loss during chromatography and assay. Some of the $-\mathrm{NCH}_{2} \mathrm{OH}$ metabolites are very unstable and others are readily analyzed without decomposition. The least stable compound considered in this study is $\operatorname{ArNHC}(\mathrm{O}) \mathrm{N}\left(\mathrm{CH}_{2} \mathrm{OH}\right) \mathrm{CH}_{3}$ which is detected by $t l c$ at $25^{\circ} \mathrm{C}$ as its $-\mathrm{NHCH}_{3}$ degradation product. Only slightly more stable is $\operatorname{ArNHC}(\mathrm{O}) \mathrm{N}$ $\left(\mathrm{CH}_{2} \mathrm{OH}\right)_{2}$ which undergoes extensive decomposition on $t l c$ at $25^{\circ} \mathrm{C}$. By chromatography at $0^{\circ} \mathrm{C},-\mathrm{N}\left(\mathrm{CH}_{2} \mathrm{OH}\right) \mathrm{CH}_{3}$ can be analyzed with only partial decomposition and $-\mathrm{N}\left(\mathrm{CH}_{2} \mathrm{OH}\right)_{2}$ with little breakdown. These metabolites, although not isolated per se, are easily derivatized to their $N$-methoxymethyl and $N$ ethoxymethyl compounds which are ade-
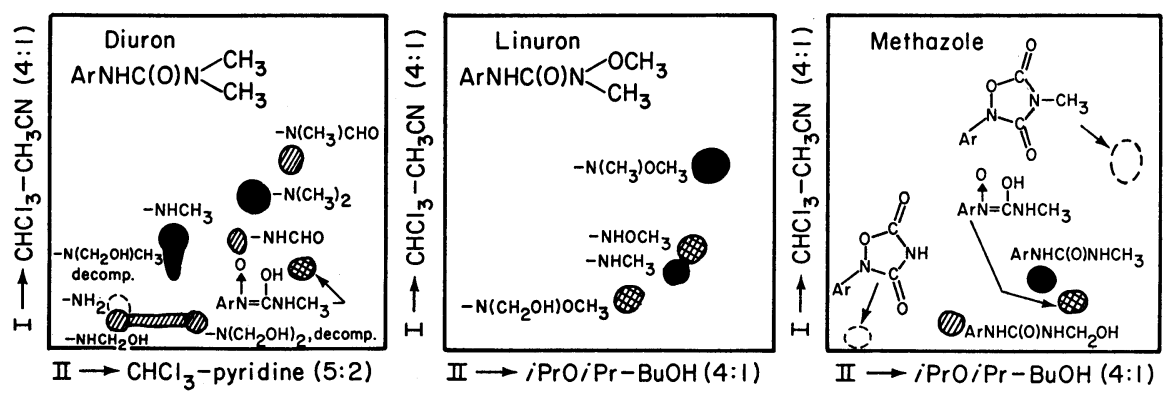

Fig. 1 Thin-layer chromatographic properties, identities and Hill reaction inhibitor potencies of diuron, linuron, methazole and their metabolites in the mouse microsomal oxidase system.

$\mathrm{Ar}=3$,4-dichlorophenyl. The lower left corner is the origin and the top and right margins are the solvent fronts for two-dimensional development.

Hill reaction inhibitor potency is designated as the minimum detectable amount in ng: $0.5-1,: 1-10, \quad: 10-200,0:>200$, i.e. detected with ${ }^{14} \mathrm{C}$ substrate but not with chloroplast-DCPIP system $\because$. 


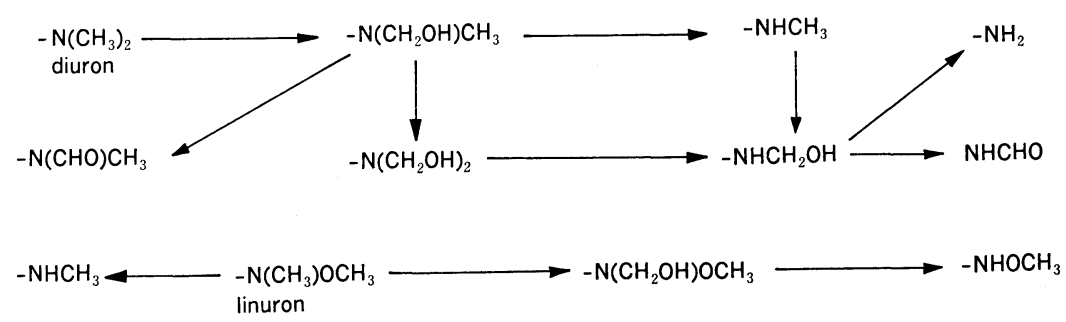

quately stable for cochromatography and analysis. $\operatorname{ArNHC}(\mathrm{O}) \mathrm{NHCH}_{2} \mathrm{OH}$ and ArNHC$(\mathrm{O}) \mathrm{N}\left(\mathrm{CH}_{2} \mathrm{OH}\right) \mathrm{OCH}_{3}$ do not degrade under normal extraction and $t l c$ conditions.

Portions of the hydroxymethyl compounds are further metabolized, i.e. diuron yields $-\mathrm{N}\left(\mathrm{CH}_{3}\right) \mathrm{CHO}$ and $-\mathrm{NHCHO}$ metabolites. This is a detoxification mechanism since the formamides are less potent inhibitors than their $-\mathrm{N}\left(\mathrm{CH}_{3}\right)_{2}$ and $-\mathrm{NHCH}_{3}$ precursors.

A very active Hill reaction inhibitor from metabolism of both diuron and methazole is identified as $\operatorname{ArN}(\mathrm{O})=\mathrm{C}(\mathrm{OH}) \mathrm{NHCH}_{3}$. This isourea- $N$-oxide is formed from $\operatorname{ArNHC}(\mathrm{O})$ $\mathrm{NHCH}_{3}$ under oxidative conditions and from methazole on hydrolysis.

Desmethyl-methazole and $\operatorname{ArNHC}(\mathrm{O}) \mathrm{NH}_{2}$ are detected as microsomal oxidase metabolites using $\left[{ }^{14} \mathrm{C}\right]$ methazole and $\left[{ }^{14} \mathrm{C}\right]$ diuron, respectively, but not with the Hill reaction method. $\quad\left[{ }^{14} \mathrm{C}\right]$ Desmethyl-methazole is also detected as an in vivo metabolite of $\left[{ }^{14} \mathrm{C}\right]$ methazole in spinach leaves. $N$-Demethylation via active metabolites ultimately detoxifies these herbicides.

\section{DISCUSSION}

Most of the observed metabolic reactions involve $N$-demethylation of each phenylurea and $O$-demethoxylation of linuron.

The isourea- $N$-oxide is of interest for several reasons. It is a new compound, a potent Hill reaction inhibitor and a metabolite of diuron and methazole. It is formed by $\mathrm{N}-$ hydroxylation of $\mathrm{ArNHC}(\mathrm{O}) \mathrm{NHCH}_{3}$ to form the herbicide ${ }^{6)} \operatorname{ArN}(\mathrm{OH}) \mathrm{C}(\mathrm{O}) \mathrm{NHCH}_{3}$ which may undergo either reduction to $\operatorname{ArNHC}(\mathrm{O})$ $\mathrm{NHCH}_{3}{ }^{7)}$, or rearrangement to the isourea$N$-oxide.

Microsomal enzyme studies monitoring Hill reaction inhibitors provide a rapid, specific and sensitive method for detection of active metabolites and evaluating activation and detoxification steps in metabolism of several types of herbicides. These experiments clearly illustrate the proherbicidal status of methazole. Diuron and linuron also yield a series of active metabolites. Many of the metabolites detected in these enzyme studies are previously known from plant metabolism investigations. ${ }^{1-4)} \mathrm{Me}-$ tabolism of the phenylureas is more completely defined than metabolism of most of the herbicides. The described system may facilitate recognizing inhibitors of photosynthetic electron transport among the metabolites of commercial or experimental herbicides and differentiating proherbicides from their ultimate herbicides.

\section{ACKNOWLEDGEMENTS}

We thank our current or former colleagues Yong Chen, Kanju Ohsawa and Luis Ruzo for advice and assistance. This study was supported in part by grants from the United States National Institute of Environmental Health Sciences (Grant No. P01 ES00049) and from Mobil Foundation Incorporated, Edison, New Jersey.

\section{REFERENCES}

1) J. R. Corbett: "The Biochemical Mode of Action of Pesticides," Academic Press, New York, 1974

2) H. Geissbühler, H. Martin \& G. Voss: "Herbicides. Chemistry, Degradation, and Mode of Action," ed. by P. C. Kearney \& D. D. Kaufman, 2nd Ed., Vol. 1, Marcel Dekker Inc., New York, pp. 209-291, 1975

3) D. W. Jones \& C. L. Foy: Pestic. Biochem. Physiol. 2, 8 (1972)

4) D. S. Frear, H. R. Swanson \& F. S. Tanaka: Phytochemistry 8, 2157 (1969)

5) J. Kováč \& M. Henselová: J. Chromatogr. 133, 420 (1977)

6) R. S. Johnson: U.S. Patent 3,254,984 (1966)

7) M. I. Luzhnova \& L. M. Shekhtman: Pestic. Biochem. Physiol. 5, 205 (1975) 
要

約

\section{フェニル尿素系除草剤の酸化的代謝によって生} ずる Hill 反応阻害剤

鈴木 孝, J.E. カシダ マウスマイクロソームの酸化酵素系により diuron, methazole および linuron の代謝を行ない, 薄層板上, 葉緑体/2,6-dichlorophenolindophenol 系で Hill 反応 阻害剤を分析し，さらに diuron および methazole に ついては ${ }^{14} C$-標識化合物を用いて検討した. 各化合物 から 3,4- $\mathrm{Cl}_{2}-\phi-\mathrm{NHC}(\mathrm{O}) \mathrm{NHCH}_{3}$ を始め, Hill 反応阻 害活性を有する代謝物が生成された。 $N$-メチル基の水
酸化，それにひき続く酸化あるいは脱アルキルにより $3,4-\mathrm{Cl}_{2}-\phi-\mathrm{NHC}(\mathrm{O}) \mathrm{R}$ 型代謝物として, diuron から $-\mathrm{N}\left(\mathrm{CH}_{3}\right) \mathrm{CH}_{2} \mathrm{OH},-\mathrm{N}\left(\mathrm{CH}_{3}\right) \mathrm{CHO},-\mathrm{N}\left(\mathrm{CH}_{2} \mathrm{OH}\right)_{2},-\mathrm{NH}-$ $\mathrm{CH}_{3},-\mathrm{NHCH}_{2} \mathrm{OH},-\mathrm{NHCHO}$, および $-\mathrm{NH}_{2}$ が, linuron から $-\mathrm{N}\left(\mathrm{CH}_{2} \mathrm{OH}\right) \mathrm{OCH}_{3}$, および $-\mathrm{NHOCH}_{3}$ が生成 した. また methazole の $N$-脱メチル, linuron の $O$ 脱メトキシ，および methazole の還元的分解が認めら れ，後二者により $3,4-\mathrm{Cl}_{2}-\phi-\mathrm{NHC}(\mathrm{O}) \mathrm{NHCH}_{3}$ が生成 する. 他の代謝物として isourea- $N$-oxide, $3,4-\mathrm{Cl}_{2}-\phi-$ $\mathrm{N}(\mathrm{O})=\mathrm{C}(\mathrm{OH}) \mathrm{NHCH}_{3}$ が diuron の酸化および methazole の分解により生成した. 